Економічні науки: збірник наукових праць Луцького національного технічного університету. - Серія "Регіональна економіка". - Випуск 15 (59). - Редкол.: відп. ред. д.е.н., професор Л.Л. Ковальська. - Луцьк: ІВВ Луиького НТУ, 2018. - 292 с.

УДК 330.341 .30

Павлюк Л.В., к.е.н., доцент

Луцький національний технічний університет

\title{
ТЕОРЕТИЧНІ ДОСЛІДЖЕННЯ ВИДІВ ТА ВИОКРЕМЛЕННЯ КЛАСИФІКАЦІЙНИХ ОЗНАК БІЗНЕС- ПРОЦЕСІВ ПІДПРИЄМСТВА
}

\author{
У науковій публікації розглядаються питання теоретичного \\ дослідження видів та виокремлення класифікаційних ознак бізнес-процесів \\ підприємства.
}

Ключові слова: бізнес-процес, вид бізнес-процесу, підприємство, класифікаційні ознаки.

Pavliuk L.

\section{THEORETICAL INVESTIGATION AND EXPLORATION OF TYPES OF CLASSIFICATION INDICATORS OF BUSINESS PROCESSES OF THE ENTERPRISE}

The scientific publication deals with the research of types of business processes of the enterprise and attempts to distinguish their classification characteristics. The study of business processes allows us to identify the stage of production, economic or marketing activity of the enterprise at which there will be a profit or loss, evaluate it and predict the situation.

As it was investigated, Modern management distinguishes between business processes that are aimed at manufacturing goods, and providing services for the end user, that is, for those who uses the results of the business process. At the same time, there are auxiliary business processes that provide the company with the necessary resources and allow the basic business processes to be implemented more effectively, as well as business management processes that are related to the problems of business process management, results obtained and process organization, etc.

With regard to the separation of classification characteristics and having conducting relevant research, we suggest using the following classification of business processes: those related to clients and business process customers; those that give added value; the level of detail of the study; definition of the boundaries of business processes.

Key words: business process, type of business process, enterprise, classification marks. 

університету. - Серія "Регіональна економіка". - Випуск 15 (59). - Редкол.: відп. ред. д.е.н., професор Л.Л. Ковальська. - Луцьк: ІВВ Луцького НТУ, 2018. - 292 с.

Павлюк Л.В.

\section{ТЕОРЕТИЧЕСКИЕ ИССЛЕДОВАНИЯ ВИДОВ И ВЫДЕЛЕНИЕ КЛАССИФИКАЦИОННЫХ ПРИЗНАКОВ БИЗНЕС-ПРОЦЕССОВ ПРЕДПРИЯТИЯ}

В научной публикации рассмотрены вопросы теоретического исследования видов и выделение классификационных признаков бизнеспроцессов предприятия.

Ключевые слова: бизнес-процесс, вид бизнес-процесса, предприятие, классификационные признаки.

Постановка проблеми у загальному вигляді і ії зв'язок з важливими науковими та практичними завданнями.

Для успішного здійснення бізнес-процесів надзвичайно важливо дослідити види бізнес-процесів підприємства та класифікаційні ознаки, за якими їх можна розрізняти. Виокремлення цього важливого поняття дозволяє виявити етап виробничо-господарської чи збутової діяльності підприємства, на якому виникне прибуток чи, навпаки, збиток, оцінити його та передбачити ситуацію.

Аналіз останніх досліджень, у яких започатковано вирішення проблеми. Питанням теоретичного дослідження бізнес-процесів підприємства, а також їх видів та виокремленню класифікаційних ознак присвятили свої наукові праці багато дослідників, а саме: Т. Дейвенпорт, В.Е. Демінг, К.С. Есселінг, Е.Г. Ойхман, Е.С. Кравченко, В. Міллар, Є.М. Попов, М. Портер, М. Хаммер, Д. Харрінгтон, Авг. В. Шеєр, Л.В. Фролова та багато інших українських та зарубіжних вчених.

Цілі статті. Головною ціллю статті $є$ розгляд основ теоретичного дослідження видів бізнес-процесів підприємства та виокремленню їх класифікаційних ознак.

Виклад основного матеріалу дослідження 3 повним обгрунтуванням отриманих наукових результатів.

Як відомо, будь-яке підприємство $є$ відкритою економічною системою, в середині якої здійснюється багато 
Економічні науки: збірник наукових праць Луцького національного технічного університету. - Серія "Регіональна економіка". - Випуск 15 (59). - Редкол.: відп. ред. д.е.н., професор Л.Л. Ковальська. - Луцьк: ІВВ Луцького НТУ, 2018. - 292 с.

різних процесів, кожен 3 яких направлений на досягнення якогось певного результату.

На сьогоднішній день, попри багато наукових досліджень дефініцій цього поняття, не існує стандартного нормативного визначення, що стосується досліджуваного терміна «бізнеспроцес». У попередніх дослідженнях, нами запропоновано під бізнес-процесом розуміти взаємопов'язаний комплекс певних дій, що призводить до перетворення вхідних ресурсів (сировини, матеріалів, інформаціі) до вихідних результатів (готової продукції чи послуг) 3 подальшою їх реалізацією аж до виникнення економічної цінності та отримання чистого прибутку. Причому, ці дії мають бути узгоджені з цілями та метою функціонування підприємства [1].

Що стосується видів бізнес-процесів підприємства, то на сучасному етапі господарювання виділяють такі основні види бізнес-процесів:

1. Основні бізнес-процеси. Вони направлені на виготовлення товарів та надання послуг для кінцевого споживача, тобто саме для того, хто використовує результати бізнес-процесу. Основні бізнес-процеси створюють додану вартість, приносячи цінність кінцевому продукту. Наприклад, безпосередне виготовлення продукції, підготовка упаковки для неї - це основний бізнес-процес. Іншими словами, основні бізнес-процеси завжди орієнтуються на отримання прибутку.

При виокремленні та описі основних бізнес-процесів, доцільно дотримуватися кількох правил, а саме:

- перелік бізнес-процесів не є сталим, їх можна як об'єднувати, так і розділяти залежно від цілей діяльності та особливостей господарювання певного підприємства;

- основних бізнес-процесів не може бути більше ніж сім, в крайньому разі дев'ять. Адже за наявності більшої кількості бізнес-процесів, «господар» чи керівник процесів не зможе ефективно керувати ними, а також сприймати та аналізувати інформацію; 
Економічні науки: збірник наукових праць Луцького національного технічного університету. - Серія "Регіональна економіка". - Випуск 15 (59). - Редкол.: відп. ред. д.е.н., професор Л.Л. Ковальська. - Луцьк: ІВВ Луиького НТУ, 2018. - 292 с.

- кожен бізнес-процес не може мати кілька «господарів» чи керівників, а лише одного;

- щоб «господар» чи керівник міг впливати на успішне здійснення бізнес-процесів і їх результати, він має мати всі необхідні ресурси і відповідні повноваження. Також повинні бути встановлені прогнозні показники ефективності як бізнеспроцесу зокрема, так і підприємства в цілому;

- за цими економічними показниками «господар» чи керівник зобов'язаний регулярно здійснювати моніторинг діяльності та звітуватися перед керівництвом про результати.

2. Допоміжні бізнес-процеси. Цей вид бізнес-процесів забезпечує підприємство необхідними ресурсами i дозволяє основним бізнес-процесам здійснюватися більш ефективно.

3. Бізнес-процеси управління. Ці процеси пов'язані 3 проблемами управління бізнес-процесом, отриманими результатами та організацією процесу тощо. Тобто, визначення вигляду, рецептури чи модифікації продукції, що виготовляється, організаційна структура управління підприємством - це бізнес-процеси управління (рис. 1).

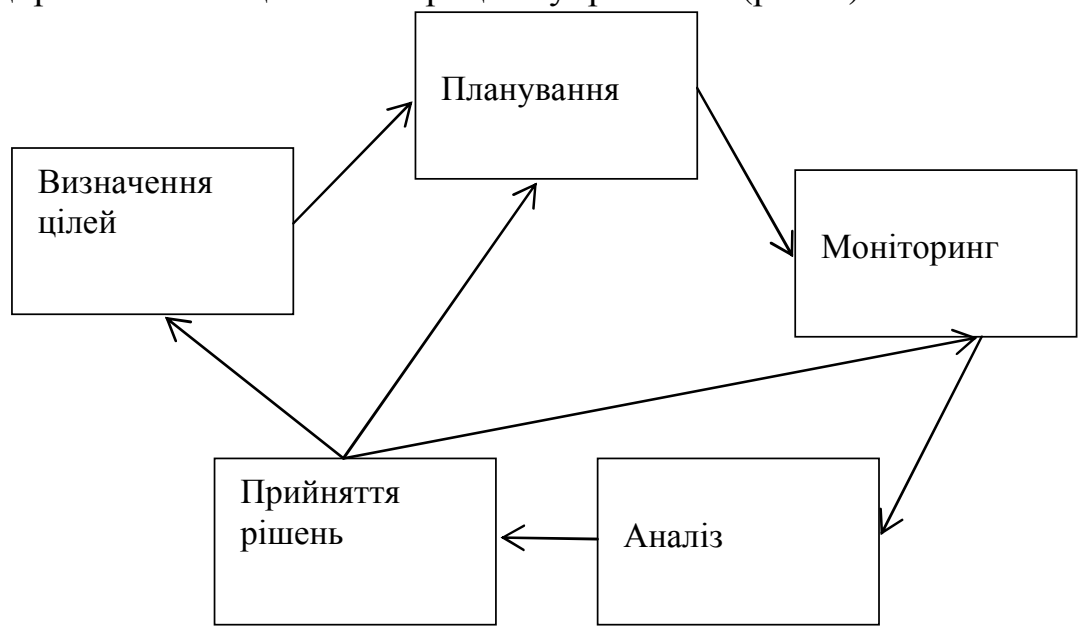

Рис. 1. Бізнес-процес управління 
Економічні науки: збірник наукових праць Луцького національного технічного університету. - Серія "Регіональна економіка". - Випуск 15 (59). - Редкол.: відп. ред. д.е.н., професор Л.Л. Ковальська. - Луцьк: ІВВ Луиького НТУ, 2018. - 292 с.

Формування бізнес-процесів необхідно розпочинати 3 вивчення попиту споживачів, що буде його початком, а кінцем бізнес-процесу повинен бути випуск готової продукції, яка буде відповідати всім вимогам споживачів.

4. Бізнес-процеси розвитку. Ці процеси пов'язані 3 проблемами розвитку підприємства, вибором його стратегії подальшого здійснення виробничо-господарської діяльності. Всі види бізнес-процесів підприємства подані на рисунку 2.

Щодо класифікації бізнес-процесів підприємства, то в сучасній науковій літературі, не існує єдиного підходу до цього процесу [2; 3; 4]. Опрацювавши джерела наукової літератури, пропонуємо таку класифікацію бізнес-процесів:

1. За відношенням до клієнтури, бізнес-процеси бувають:

- зовнішні;

- внутрішні.

2. За відношенням до добавленої вартості:

- основні (безпосередньо добавляють вартість);

- допоміжні (вони не добавляють вартість, але збільшують цінність продукції);

3. За рівнем детальності дослідження бізнес-процесу вони бувають:

- верхнього рівня;

- детальні;

- елементарні (ті, які не потребують детального опису);

- прості.

Верхній рівень опису бізнес-процесів відповідає процесам, що спрямовуються керівником чи його заступниками. Другий рівень, як правило, розглядається на рівні керівників великих підрозділів підприємства. Третій рівень - це рівень процесів (функцій) підрозділів і функціональних відділів. На четвертому рівні - описують функції чи операції, що виконуються на робочих місцях. 
Економічні науки: збірник наукових праць Луцького національного технічного університету. - Серія "Регіональна економіка". - Випуск 15 (59). - Редкол.: відп. ред. д.е.н., професор Л.Л. Ковальська. - Луцьк: ІВВ Луцького НТУ, 2018. - 292 с.

\section{Основні бізнес-процеси}

Створюють додаткову вартість продукту

Виготовляють товар, який цінний для клієнта

Формують результат, за який клієнт готовий заплатити гроші

Направлені на отримання прибутку підприємством Допоміжні бізнес-процеси

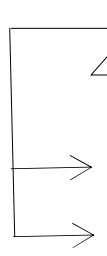

Підтримують основні бізнес-процеси і процеси розвитку

Створюють інфраструктуру підприємства

\section{Бізнес-процеси розвитку}

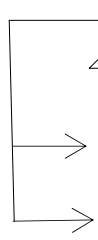

Спрямовані на отримання прибутку в довгостроковій перспективі

Забезпечують вдосконалення діяльності підприємства

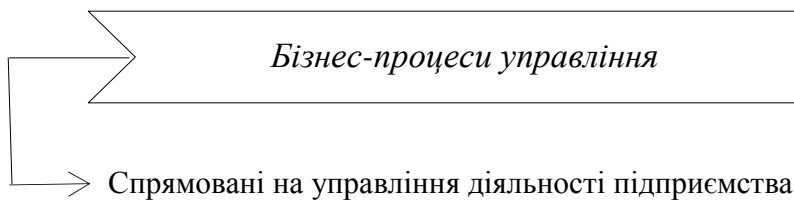

Рис. 2. Види бізнес-процесів підприємства 
Економічні науки: збірник наукових праџь Луцького національного технічного університету. - Серія "Регіональна економіка". - Випуск 15 (59). - Редкол.: відп. ред. д.е.н., професор Л.Л. Ковальська. - Луиьк: ІВВ Луиького НТУ, 2018. - 292 с.

4. За визначенням меж (границь) дії бізнес-процесів, вони поділяються так:

- за структурою підприємства;

- за результатами бізнес-процесу - випущеною продукцією;

- за ланцюжком створення цінності.

За першою класифікаційною ознакою (структурою підприємства) описуються укрупнені процеси структурних підрозділів верхнього рівня, потім кожен 3 цих процесів описується як сукупність процесів більш низького рівня і так далі. Але те, що підприємство описується в термінах функціональної діяльності саме і $є$ тим суттєвим недоліком цього методу: різні бізнес-процеси описуються як діяльність, що розподіляється за різними функціональними підрозділами i спеціалістами, що порушує основний принцип реінжиніринга «один процес - один підрозділ - один бюджет - один господар процесу».

За другою функціональною ознакою (результатами бізнеспроцесу) спочатку описується продукт компанії в цілому та на всіх стадіях життєвого циклу. Цей підхід дещо складніший, його набагато важче впроваджувати, але він дозволяє оптимізувати діяльність підприємства, впровадити його ефективне бюджетування, різко знизити виробничі витрати, надати «прозорості» бізнесу.

За третьою класифікаційною ознакою, бізнес-процеси описуються 3 погляду на описану М. Портером теорію створення цінності [5]. В ній виділяються основні (первинні) бізнес-процеси, що забезпечують створення споживчої цінності продукції i підтримуючі (допоміжні) бізнес-процеси, що забезпечують функціонування бізнесу i супроводжують створення продукту на всіх стадіях життєвого циклу. При вирішенні питання про межі бізнес-процесів, М. Портер запропонував, що границі бізнес-процесів знаходяться там, де створюється добавлена споживча цінність продукту.

Висновки. Отож, теоретичні дослідження сутності поняття та видів бізне-процесів підприємства набувають 
Економічні науки: збірник наукових праиь Луиького національного технічного університету. - Серія "Регіональна економіка". - Випуск 15 (59). - Редкол.: відп. ред. д.е.н., професор Л.Л. Ковальська. - Луиьк: ІВВ Луиького НТУ, 2018. - 292 с.

важливого значення в сучасній теорії економічної науки. А виокремлення найбільш важливих їх класифікаційних ознак дозволяє підвищувати успішність та ефективність їх здійснення на підприємствах.

1.Павлюк Л.В., Оксенюк К.І. Теоретичні основи дослідження бізнеспроцесів на підприємстві. - Економічний форум / науковий журнал, №4, 2017. - 300 c. - C. $148-151$.

2. Август-Вильгельм Шеер. «Бизнес-процессы. Основные понятия. Теория. Методы». Издание 2-е, переработанное и дополненое. / Пер. с англ. Михайлова Н.А. - М.: Весть - МетаТехнология, 1999. - 151 с.

3. Фролова Л.В. Формирование бизнес-модели предприятия [текст] Учебник. / Л.В. Фролова, Е.С. Кравченко. - К.: Центр учебной литературы, 2012. $-384 \mathrm{c}$.

4. Серединська В.М. Загородна О.М. Бізнес-процеси підприємста: сутність та класифікація // Актуальні проблеми теорії i практики бухгалтерського обліку, аудиту, аналізу й оподаткування в Україні: сучасний стан та перспективи розвитку. Матеріали міжнар. наук.-практ. конф. (м. Кам'янець-Подільский, ПДАТУ, 14 грудня 2016 р.) / Тернопіль: Крок, 2016. $-247 \mathrm{c}$.

5. Портер М. Конкуренция: [учеб. пос.] / М. Портер. - МСПб; К.: Изд. дом «Вильямс», 2000. - 495 с. 